\title{
Total Testosterone Measurement
}

National Cancer Institute

\section{Source}

National Cancer Institute. Total Testosterone Measurement. NCI Thesaurus. Code C74793.

The determination of the amount of free and bound testosterone present in a sample. 